\title{
Agustin de Betancourt's Telegraph: Study and virtual reconstruction
}

\author{
Ricardo Villar-Ribera ${ }^{1}$, Francisco Hernández-Abad ${ }^{1}$, José Ignacio Rojas-Sola ${ }^{2}$, \\ David Hernández-Díaz ${ }^{1}$ \\ ${ }^{1}$ Polytechnic University of Catalonia, Department of Engineering Graphics, Barcelona, Spain. \\ ${ }^{2}$ University of Jaén, Department of Engineering Graphics, Design and Projects, Jaén, Spain.
}

\begin{abstract}
The transmission of information has gone through various stages of evolution throughout its history. A stage before that of the electric telegraph was the so-called aerial/optical telegraph. It was developed towards the end of the $18^{\text {th }}$ century and was in service until the middle of the $19^{\text {th }}$ century. Chappe's system was widely used in France, and was the first to be in consistent use. However, a new and technologically superior system was developed soon afterwards which superseded it. Its inventor was Agustín de Betancourt, considered by some authors one of the founders of the Theory of Machines and Mechanisms, who, together with the distinguished clockmaker Breguet, presented it to the French Authorities in the turbulent decade of the 1790s.

This article presents a historical review of this telegraph and analyses its technical characteristics. It presents analytically, numerically and graphically some of the statements made about the telegraph, and corrects other subsequent observations. Lastly, a detailed reconstruction of the telegraph is made using different advanced CAD techniques, which provide an accurate static and dynamic view of each of its parts.
\end{abstract}

Keywords: Agustin de Betancourt, telegraph, virtual reconstruction, computer animation.

\section{Biographical introduction}

Agustín de Betancourt was a Spanish engineer who work in the service of two countries, Spain and Russia. He was born in the Canary Islands in 1758, and moved to Madrid in 1778 where he studied in the Reales Estudios de San Isidro, and subsequently in the Real Academia de Nobles Artes. In 1784 he moved to Paris in order to continue his studies in the École des Ponts et Chausées, where he developed a friendship with Gaspard de Prony.

After briefly returning to Spain, the Spanish Government engaged him to produce a collection of machines, on plans and in models, which would later become the Real Gabinete de Máquinas, the seed of the future Oficina Española de Patentes y Marcas (Spanish Patents Office) and of studies in Industrial Engineering. 
In 1788 Betancourt moved to England to continue his work, and it was on this trip that he saw (although not in detail) a double-acting steam engine. As a result he published Mémoire sur une machine à vapeur à doublé effet (1789), and supervised the work of the construction of various engines for the Perier brothers. [1]

Owing to the situation caused by the French Revolution, Betancourt returned to Spain in 1791, where he founded the Real Gabinete de Máquinas (Royal Machines Cabinet), situated in the Palacio del Buen Retiro (1792).

1793 saw him return again to England, where we stayed for three years studying steam engines, and until 1797 he was in France, during which time he presented a memoir on a new telegraph together with the clockmaker Breguet.

Betancourt returned to Paris at the end of 1797 to present the improved version of the telegraph, which received academic acclaim, but which was never implemented owing to the opposition of Chappe, Director of the French Telegraph Service.

Upon his return to Spain, Betancourt took charge of the construction of the telegraph line which was to link Madrid and Cadiz, but which was not completed owing to financial problems, and only reached as far as Aranjuez, some $40 \mathrm{~km}$ from Madrid.

In 1803 he created the Guild of Ingenieros de Caminos y Canales (Civil Engineers), although he began teaching the previous year, and in 1808 he began working for the Tsar of Russia; here he undertook a similar role to that he carried out in Spain, in charge of the Guild of Ingenieros de Caminos y de la Escuela preparatoria.

In 1808, before leaving for Russia, he published along with José $\mathrm{M}^{\mathrm{a}}$ de Lanz the "Essai sur la composition des machines", considered to be the first work on the Theory of Machines and Mechanisms, and which would be a teaching text in European universities for the following fifty years. The second edition was published in 1819 (without Hachette's introduction), and the third edition in 1840, after Betancourt's death. It was soon translated into English $(1820,1822)$ and German (1829). [2-4]

In Russia Betancourt undertook important organizational and teaching roles, founding the foremost engineering school in the country, and his work contributed notably to the development of Russian technical education. [5, 6]

Agustin de Betancourt died in St. Petersburg in 1824.

\section{Historical Background}

\subsection{Early telegraph history [7-9]}

From the beginnings of history peoples have sought a system which allowed them to communicate quickly over long distance. The means available were fire and smoke, given the limitations of distance of acoustic signals (Although Caesar describes in "De bello gallico" how the Gauls communicated across distance, this cannot be considered as a precursor of the telegraph, as it used voice communication.

Signal fires and beacons were used to transmit news of events during the Trojan war $\left(12^{\text {th }}\right.$ century B.C.) 
Polibio, a Greek historian of the $2^{\text {nd }}$ century B.C., described a system of communication of information based on clepsydra, which was used during the first Punic War ( $3^{\text {rd }}$ century B.C.). He also reported a primitive telegraph using groups of five torches. This system was able to transmit messages, as the alphabet was made up of 25 letters (by dividing the alphabet into five groups, the first signal indicated the group and the second the position within the group). This system was adopted by the Romans, who established a network of communication towers. Trajan's Column shows one of these towers.

In the Middle Ages smoke signals were in use. This was the system used to inform the King of Castile, Enrique III, of the birth of his son, Juan II.

In 1340 the Castillian army used different flags to communicate coded orders and messages in the campaign against the King of Aragon. There are prior references in the "Código de las Partidas" of Alfonso X to a system of naval communication. It would not be until 1742 that the Spanish navy adopted a code of signals using 10 flags, each of which stood for a number. This system was later adopted by the navies of different countries.

A system of beacons was used in England to warn of the approach of the Spanish Armada.

In 1651 a Capuchin Friar proposed the used of telescope for long-distance communication, with a system of coded signals. This system was never implemented.

Robert Hooke proposed to the Royal Society in 1684 an optical telegraph system which was not put into practice.

It was the social changes of the $18^{\text {th }}$ century, particularly those brought about by the French Revolution, which finally led to the appearance of an effective telegraph. This was the Chappe brothers' telegraph, considered as the first real telegraph (and Chappe is considered as the father of telecommunication). Claude Chappe was the first to use the term 'telegraph'

(from the Greek tele, at or to a distance, and graphia, to write or draw).

\subsection{Chappe's Telegraph}

In 1794 Chappe's telegraph [10] came into use between Lille and Paris (figure 1). The previous year the Committee of Public Health ordered the construction of the first telegraph line which linked Lille and Strasbourg, through Paris, and which came under the jurisdiction of the War Ministry. Owing to the limitations of mechanics, Chappe called on the services of the clockmaker Breguet, who designed the necessary mechanisms to move the telegraph and construct the corresponding models $[11,12]$ (therefore, we should talk about the ChappeBreguet telegraph).

This all coincides with the time of 'Terror', which saw the death of many French people at the hands of the revolutionary fanaticism of Robespierre. Because of this, Breguet fled to his native Switzerland between 1793 and 1795 to escape the guillotine; this is possibly the reason why his name disappeared from the telegraph, leaving Chappe as its sole creator. 


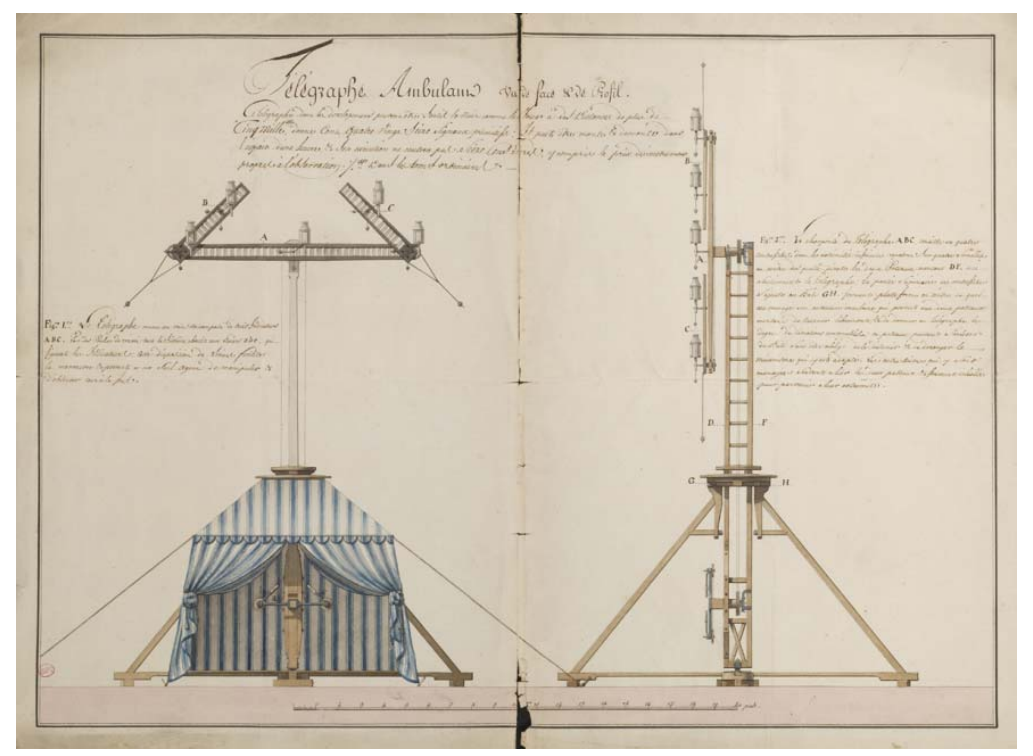

Figure 1. Chappe's Telegraph. Field version [13].

Chappe's telegraph consisted of a long arm (regulator), with two smaller arms at the ends (indicators). Both the regulator and indicator arms moved in steps of $45^{\circ}$, giving four positions for the regulator, and eight for the indicators. Chappe removed from the system the position in which the indicators overlapped with the regulator, resulting in seven positions for each indicator. Therefore there were 196 different positions, although finally only 92 were used, as the oblique positions of the regulator were used by the receiving station to confirm reception of the code.

In order to design the code, Chappe had the help of his cousin Léon Delauney, who was familiar with coding following his work in the French consulate in Lisbon. The small number of people who were in charge of the code were called directors. The directors formed the messages from words and phrases, which were written in the code books. The telegraph operators (called estacionarios), transmitted two signals: one for the page of the code book, and the other for the line of the page. There were various coding versions, notable among which was the one which had 92 pages, each with 92 lines.

The system was reasonably effective for its time. An example of this is that a signal could travel from Paris to Lille in just 9 minutes. However, there were limitations. The visibility between stations was not ideal, and this frequently led to transmission errors. To address this problem, Chappe introduced auxiliary stations which came into service in low-visibility conditions. He also considered increasing the size of the regulator from 4 to 15 metres, although this was never implemented. In addition, he consulted Gaspard Monge, who proposed raising the number of arms from two to seven, although this suggestion was also not put into practice [14].

\subsection{Murray's Telegraph}

At about the same time, other types of telegraphs were being developed. One of these was developed in Sweden by Edelcranz (figure 2). This was working by 1794, and consisted of a system of 10 screens, with each one pivoting through $90^{\circ}$ in two positions, visible and not visible. The different positions of the screens formed numerical combinations which could be translated into letters, words or sentences using code books. 


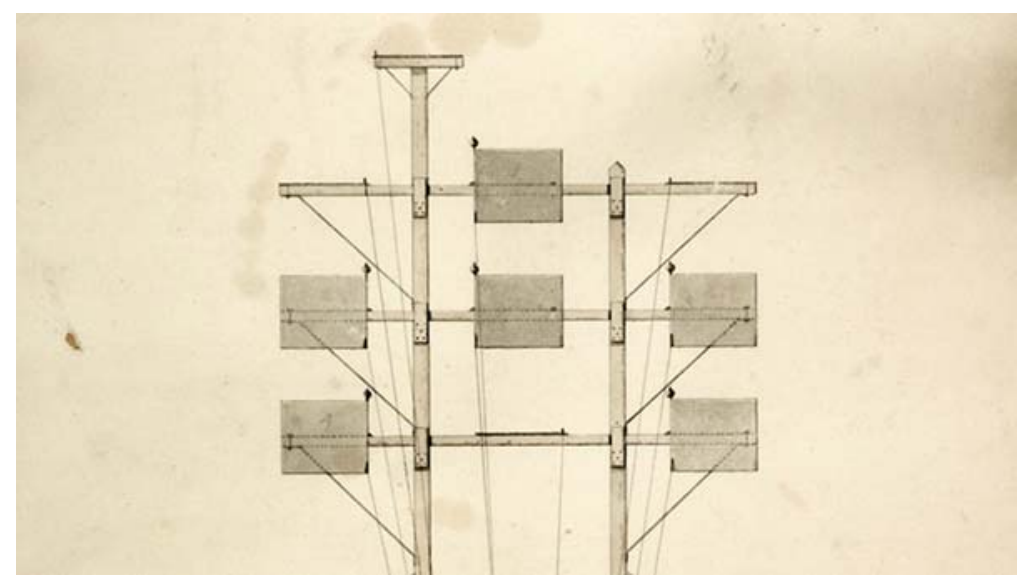

Figure 2. Edelcrantz's Telegraph [15].

Murray's telegraph, which was inspired by Edelcrantz's, had six screens on two columns, which allowed enough combinations $\left(2^{6}\right.$, that is, 64$)$ to transmit messages. There were three operatives, two of whom moved the screens and one who acted as observer. At the beginning of 1796 a line of 15 stations was already in service, which is possibly the line seen be Betancourt.

\subsection{Betancourt's telegraph}

The first description of Betancourt's telegraph is to be found in the manuscript [16], which was presented to the Executive of the French Republic with the help of the député D'Eymar on the $23^{\text {rd }}$ Brumaire of the Year V (13 ${ }^{\text {th }}$ November 1796). In his presentation, D'Eymar confirmed that Breguet is the designer of the telegraph mechanisms of Chappe's telegraph, and informed that Betancourt "has observed the installation of English telegraphs". This document includes a description of the invention and a colour-ink drawing of the mechanism; however, the graphical documentation is incomplete, as there is no drawing of the complete telegraph.

This memoir was sent to Prony. In Prony's report on the telegraph [17], there is a plan which must be either the original drawing by Betancourt or a copy, as it is a true representation of the mechanism that was present in the first document. This report concluded that the new telegraph was superior to the one it set out to replace, in the following features:

- It was simpler to use and easier to build.

- The transmission of messages was faster and with fewer errors.

- It didn't need highly-qualified workers.

- It was cheaper than Chappe's telegraph.

- It could be fixed or mobile (this was also the case with Chappe's telegraph).

This first version (figure 3) was opposed by Chappe, who considered that his version was superior [18, 19], and belittled the importance of the new invention (he even called it a copy). This led to a public clash between Chappe on one side, and D'Eymar, Breguet and Betancourt [20] on the other. 


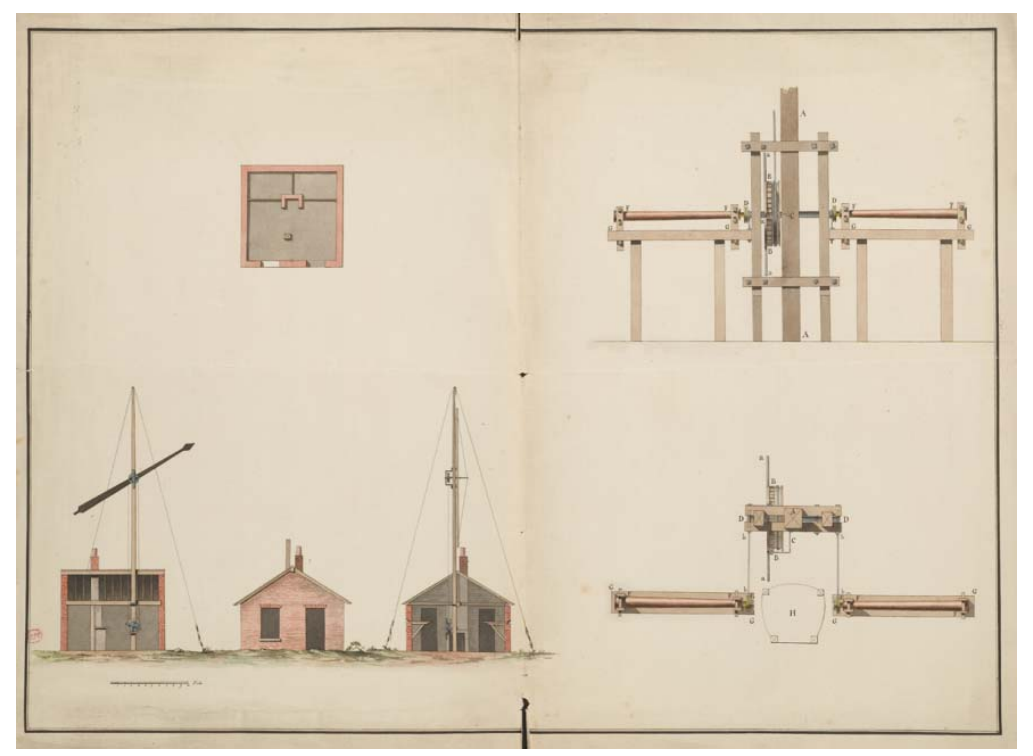

Figure 3. First telegraph. Synchronsim of telescopes and general views.

This clash led Betancourt to write a second memoir [21] (5th of Frimaire of year VI), which carried the signature of both Betancourt and Breguet, and which was presented to the Science Academy in Paris at the end of 1797. The Academy appointed a commission of experts whose prestige would be sufficient to give credibility to their conclusions [22]. They were Lagrange, Laplace, Borda, Prony, Coulomb, Charles and Delambre.

This second manuscript consisted of a 16-page manuscript, and three pages of black and white plans. The plans used a metric scale, unlike the previous manuscript which had used feet and inches.

The memoir was in two parts, the first devoted to the description of the telegraph, and the second in which the authors proposed a series of ideas relating to telegraphic language. The first part opened with a declaration of the reasons that had led the authors to present the telegraph to the Academy, that is, the justification of the invention. These reasons were the following improvements in comparison with Chappe's telegraph:

- Mechanical simplification

- Increased transmission speed

- Lower costs

The following point is the description of the first two plans. The first plan contains the raised and cross-section views of the telegraph (it should be noted that while the mobile part, called the arrow by the authors, is shown in oblique position in the raised view, in the cross-section view it is full size). The second plan contains a blown-up view of the lower part, in front and raised views. The description is detailed, and each part is identified with letters, in keeping with the style of the period.

This second memoir, in addition to the improvements which are shown on the plans (as well as the fact that the arrow turns on the upper end of the post, it has also been redesigned to differentiate clearly the upper and lower parts of the arrow), responds to some objections which had been made against the telegraph, and which are outlined in the next section. 


\section{Bases of the telegraph}

The telegraph consists basically of a mobile element, called the arrow, attached to a vertical post. At the lower end of the arrow there is a perpendicular cross piece, which serves to distinguish the upper part of the arrow from the lower part.

The telegraph transmits angular positions of the arrow. In order to read these positions correctly, each telegraph has two telescopes, which are synchronized with the movement of the arrow using pulleys and chains. The first is used to observe the signal of the transmitter telegraph, and the second to verify that the receiver telegraph has received the signal correctly.

In order to guarantee the accuracy of the signals, the telescopes have a vertical line which the telegraph operators lined up with the transmitter arrow. When the winch was moved, the arrow and telescopes moved simultaneously, so that when the line of the telescope coincided with the transmitter arrow, the telegraph's own arrow was already in the required position.

The objections which are taken up in the second memoir with respect to the functioning of the telegraph are the following:

- The first referred to the difficulty to distinguish small angles on days with adverse weather conditions. The authors clarified that the objective was not to measure angles, but rather to line up two parallel lines, the arrow and the visual line.

- The second was the need to place the mobile stations closer together. This was countered by the fact that observed part is much larger than the part it replaces.

- The third objection is the most interesting. This deals with what happens when three stations are not aligned. This is a frequent problem, as the terrain makes it impossible to align all the different stations which make up a telegraph line.

This third objection requires more detailed study.

\subsection{Study of the telegraph angles}

In the telegraph, two angles need to be considered (figure 4). The angle (I) between the turning planes of the arrows, and the angle between the arrow and the vertical $(\varphi)$.

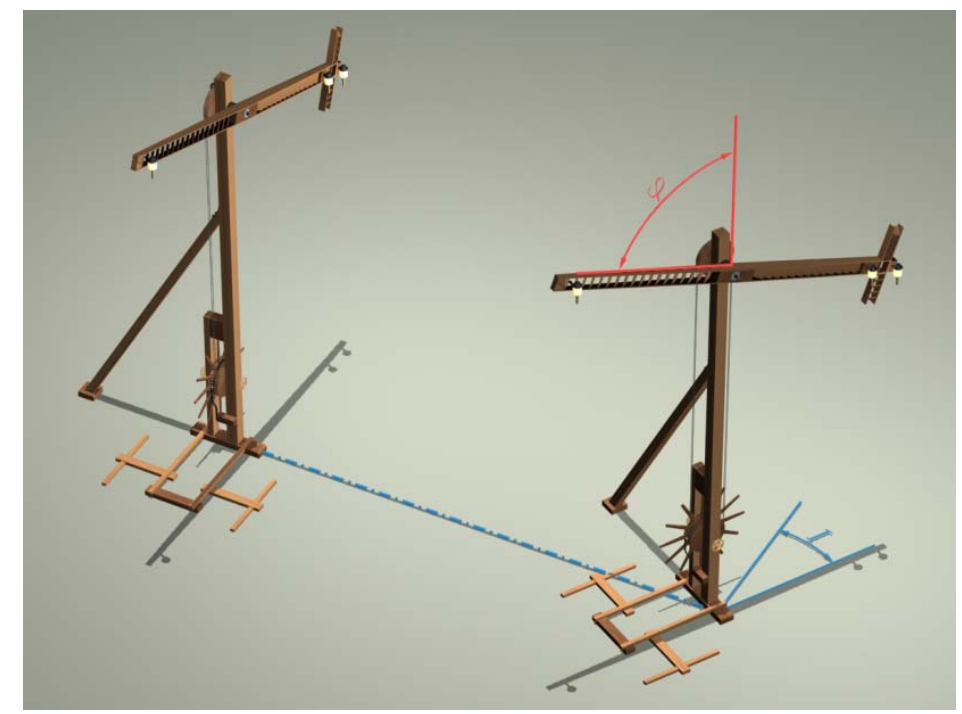

Figure 4. Angles of the telegraph. 
Various cases are studied in the memoir. For small angles, the error is smaller and can be considered negligible, but the error needs to be corrected for larger angles.

\subsection{Calculation of observed error}

The following is a calculation of the angle observed from a slanted plane (figure 5).

Let $\mathrm{M}$ be the telegraph arrow, $\pi$ the turning plane of the arrow (defined as perpendicular to the axis), and $\pi$ ' the plane on which $M$ will be projected. I is the angle formed between planes $\pi$ and $\pi$ '. The angle of turn of the arrow with respect to the vertical will be called $\varphi$.

A system of coordinates $\mathrm{X}, \mathrm{Y}, \mathrm{Z}$ is situated such that plane $\mathrm{XZ}$ is the turn of the arrow. For plane $\pi$ ' the $X$ axis does not vary, while the $Z$ and $Y$ axes do vary. $Z$ ' is the result of reducing $Z$ by multiplying it by the cosine of I

Analytically:

$$
\begin{gathered}
M_{\mathrm{X}^{\prime}}=\mathrm{M}_{\mathrm{X}} \\
\mathrm{M}_{\mathrm{z}^{\prime}}=\mathrm{M}_{\mathrm{z}} \cdot \cos \mathrm{I}
\end{gathered}
$$

The resulting angle $\left(\varphi^{\prime}\right)$, is formed by $M^{\prime}$ with the vertical Z'; therefore, this angle must be according to angle $\varphi$.

$$
\begin{gathered}
\tan \varphi=\frac{M_{x}}{M_{z}} \\
\tan \varphi^{\prime}=\frac{M_{x^{\prime}}}{M_{z^{\prime}}}=\frac{M_{x}}{M_{z} \cdot \cos I}
\end{gathered}
$$

From these expressions, we have:

$$
\tan \varphi^{\prime} \cdot \cos I=\tan \varphi
$$




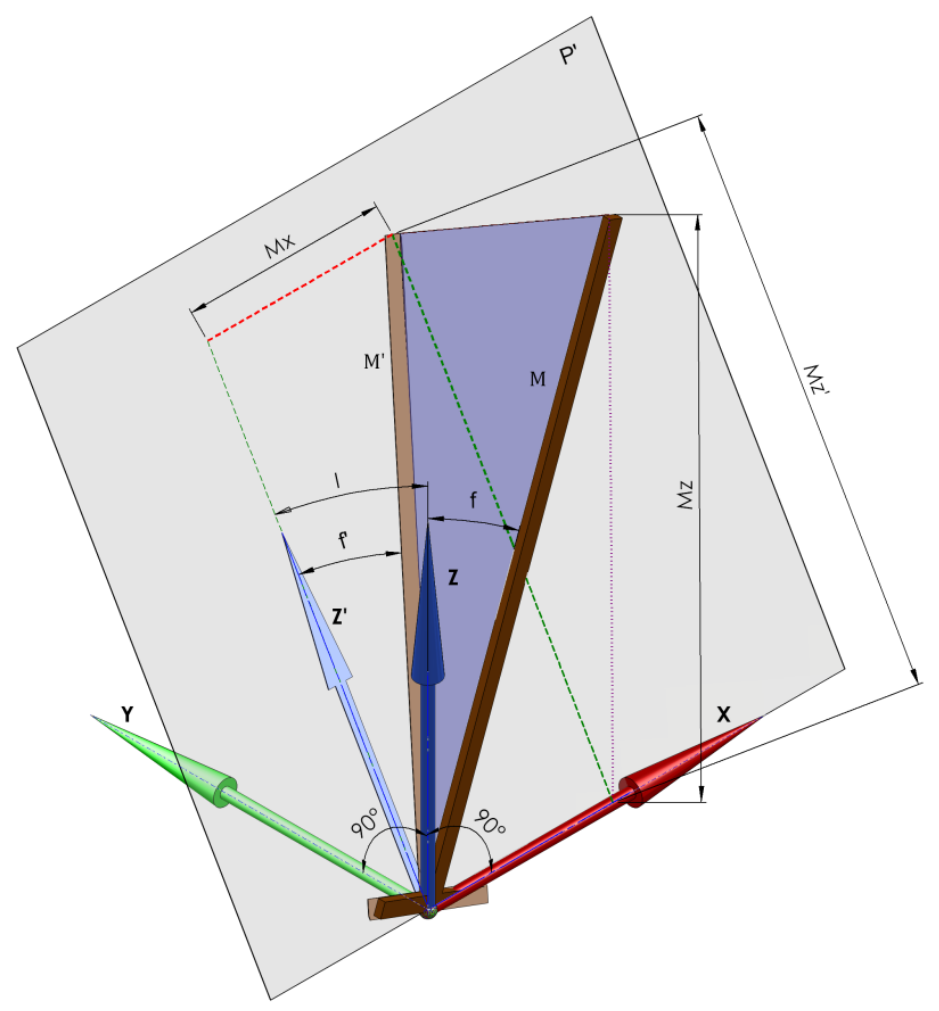

Figure 5. System of coordinates projected onto a slanted plane.

According to the memoir, for an angle between the turning planes of the arrows (I) of $30^{\circ}$ and that of the arrow with the vertical $(\varphi)$ of $45^{\circ}$, the difference is $4^{\circ} 6^{\prime}$ (Note that Betancourt, who wrote the memoir, used the singular for this supposition "..l'angle BCD que je suposse être...", which shows the importance of Betancourt's role in comparison with that of Breguet. It is also clear that the manuscript was written by Betancourt, and then Breguet added his signature, "difference trop considérable pour être negligée"). This value is exactly the same as that which is verified analytically and graphically.

\subsection{Solution proposed by Betancourt}

Given the deviation shown above, the solution which Betancourt put forward was to use gimbals for transmission. In fact, the expression shown above is exactly the same as that which relates angles for a gimbal joint

$\tan a^{\prime}=\tan a \cdot \cos I[23]$

(therefore, we may wonder whether Betancourt arrived at this expression in his Essai sur la composition des machines after tackling this problem). However, even in 2007, many researchers were unaware that in Betancourt and Lanz's work the expression of the gimbal is present. A. Mills [24] states that the first time the expression appears is in 1845, in the Traite de Mécanique apliquée aux machines by Poncelet. Poncelet was an alumnus of the Polytechnique, and therefore was familiar with the work of the Spaniards).

(The French version of the Essai sur la composition des machines contains an error, which cannot reasonably be attributed to the authors, as the cosine is divided by $\mathrm{R}$, which makes the expression incoherent. This $\mathrm{R}$ is not present in the explicative text preceding the expression) 
where $a^{\prime}$ is the angle formed by the driven axis, $a$ the angle formed by the driving axis, and $I$ the angle formed by the two axes.

This article also shows a graphic solution to the movement of the gimbal joint (figure 6), as the incorporation of this process is very interesting owing to its simplicity. It is sufficient to bear in mind that for the chosen projections, the angle of the projected crosspiece is always $90^{\circ}$, as in both projections one of its axes is drawn with 1:1 scale (theorem of three perpendiculars). In order to draw projections $\mathrm{A}$ and $\mathrm{B}$, no other data than those shown in the picture are necessary. This system of resolution of the gimbal joint is a personal addition by the authors and to the best of our knowledge is unpublished.

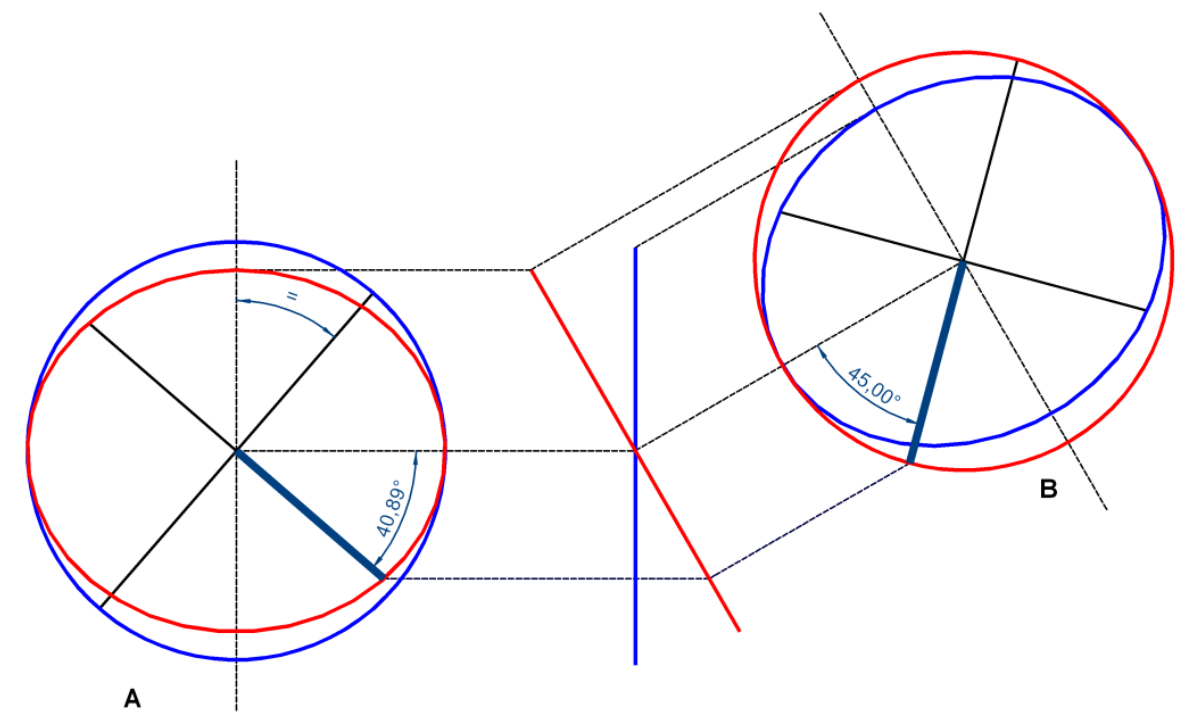

Figure 6. Graphic resolution of a gimbal joint.

Changing the expressions above, we find that for a gimbal joint, the entrance angle is the same for the projection of the exit angle on a perpendicular plane to the entrance axis, as Betancourt stated and demonstrated.

In this simulation it can be seen (figure 7) that while the turning angles are different, in the direction of the auxiliary project the real turning angle (red) and the projected angle on the other axis (grey) are the same. The red angle marks the direction of the line of the telescope, while the grey represents the line of the arrow.

Therefore, if they are appropriately combined, the use of gimbal joints can solve precisely the problem (in addition, in a double gimbal joint, the entrance and exit turning angles are equal, if the angles between the axes are also equal). 


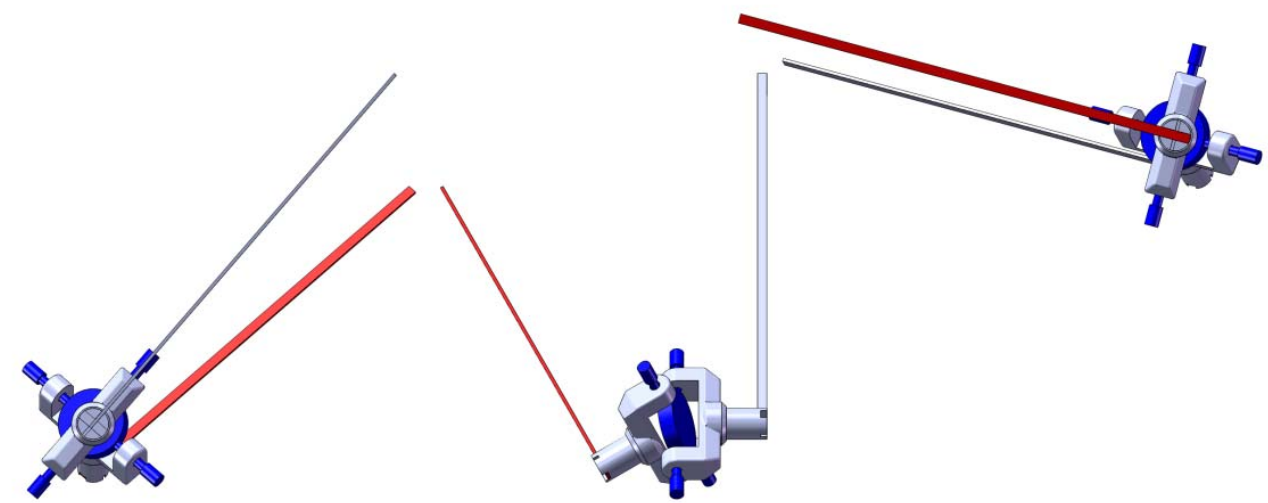

Figure 7. Simulation of the movement of the gimbal joint.

The way in which this is done is drawn in the upper part of the third plan of the memoir. That is, the first gimbal joint connects the telescope which observes the previous station to the winch (the arrow), which in turn is connected to the telescope which observes the following station. Therefore, the entrance and exit turning angles are the same, while the angle of the arrow is different; however, its projection seen from the previous and following stations coincides with those of the telescopes. In this way, although the different stations are not aligned (Figure 8), the angle observed from any station (with respect to the previous and subsequent stations) is the same, and this is the value through which the telescope turns.

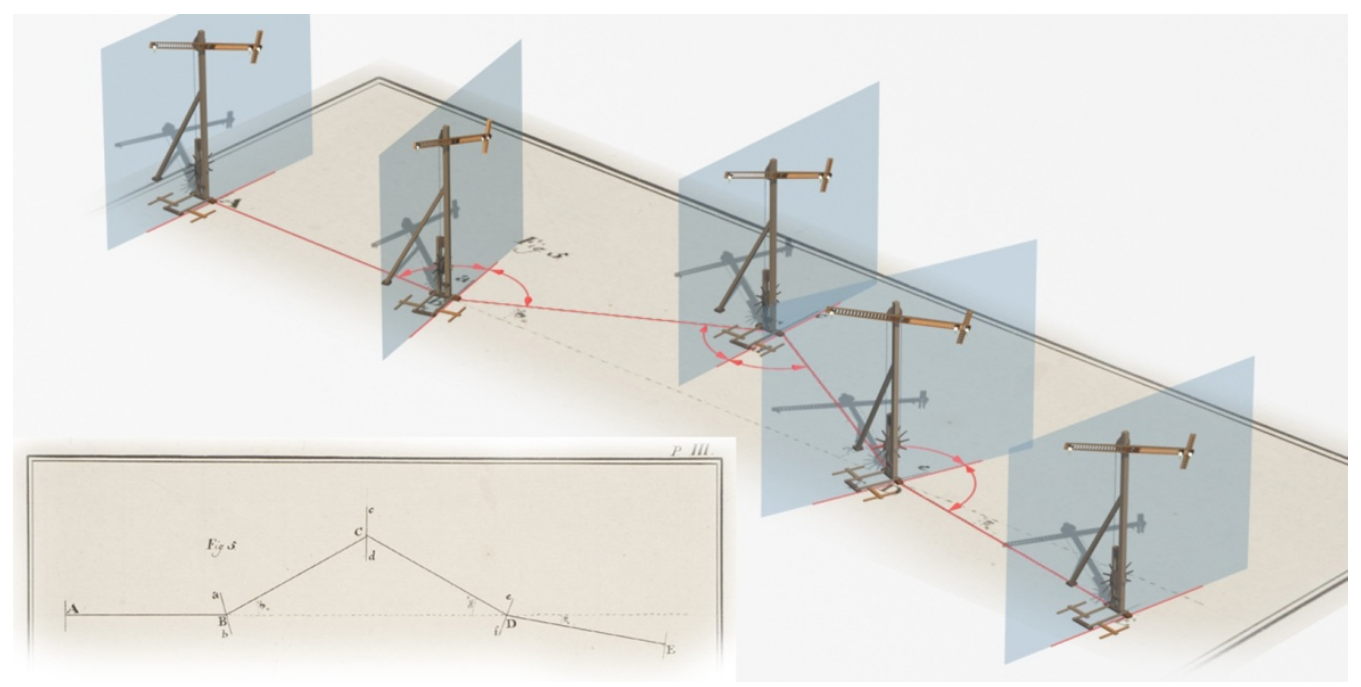

Figure 8. Positioning of stations.

In figure $8, a b, c d$, ef define the planes in which the arrows turn, and which coincide with the bisectors of the angles formed by the stations. This means that the orientation angles of the gimbal joints are the same for the entrance and the exit. 


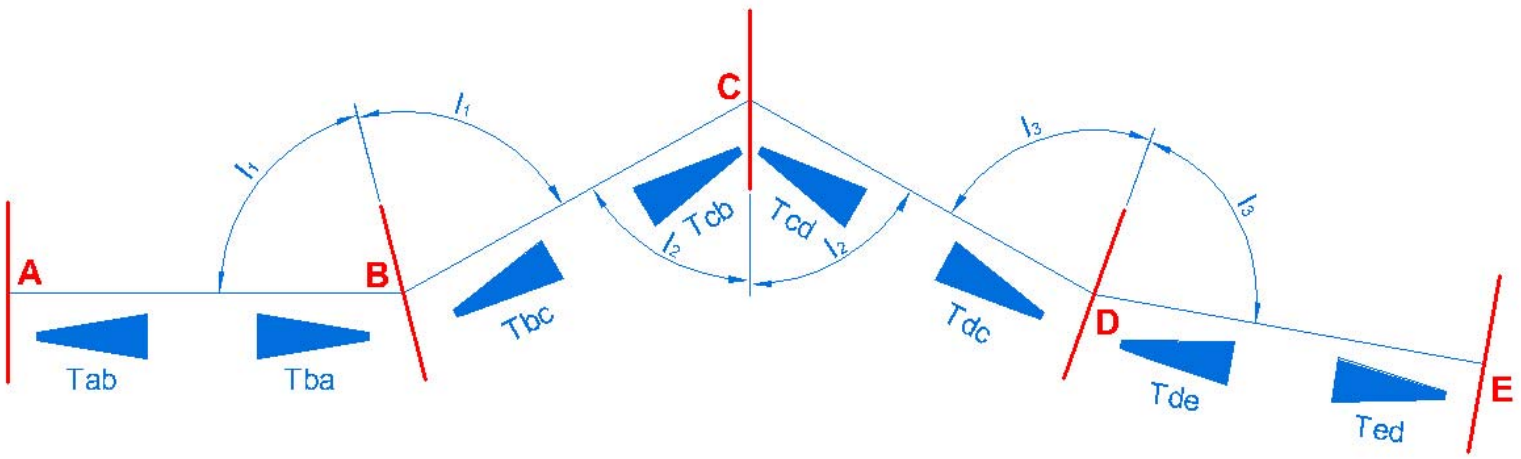

Figure 9. Schematic positioning of stations with telescopes.

We can examine in greater detail a stretch of the telegraph line (figure 9). A, B and C are three non-aligned stations. Tab is the telescope at A which observes $\mathrm{B}$. Tba is the telescope at $\mathrm{B}$ which observes $\mathrm{A}$, and therefore Tbc is the telescope at $\mathrm{B}$ which observes $\mathrm{C}$. The arrows are $\mathrm{Fa}$, $\mathrm{Fb}$, and $\mathrm{Fc}$.

The angle $\mathrm{ABC}$ is $2 \mathrm{I}_{1}$, and the turning plane of $\mathrm{Fb}$ is the plane which bisects $\mathrm{ABC}$, so the angle between the turning plane of $\mathrm{Fb}$ and the stretch of the line $\mathrm{AB}$ is $\mathrm{I}_{1}$, which is the same for $\mathrm{BC}$.

At a given moment, Fa turns through an angle $\alpha$. The telegraphist at B turns the telescope Tba until its angle coincides with that of $\mathrm{Fa}$. As $\mathrm{Fb}$ is joined via the gimbal joint, it turns through a different angle according to the relationship $\tan \alpha^{\prime}=\tan \alpha \cdot \cos \mathrm{I}_{1}$. The observer must check that the message has been correctly received, and observe the position of $\mathrm{Fb}$. As it is observed from an angle $\mathrm{I}_{1}$, the value observed is given by the expression shown in 3.2, and the angle observed from $\mathrm{A}$ is also $\alpha$.

The angle through which the other telescope at B, Tbc, turns, is the same as that of Tba, as they are joined by a double gimbal joint and the entry and exit angles are equal. The same situation occurs at the following station, $\mathrm{C}$.

This process is repeated at all the stations. While the telescopes turn through equal angles, the arrows turn through different angles, but the observed angle is the same for all the stations. 


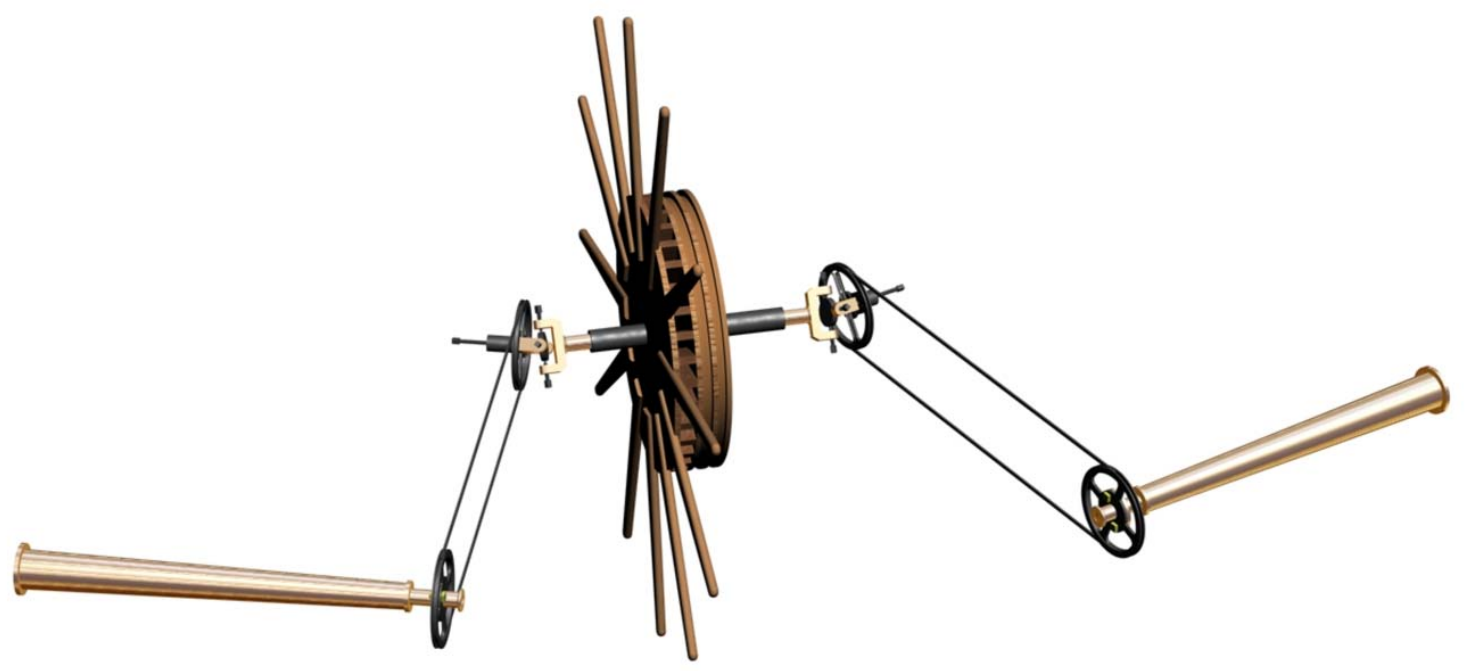

Figure 10. Synchronism of the system. Application of gimbal joints to maintain the synchronism of the system, with a central winch.

\section{Implementation}

The commission which studied the second memoir proposed a comparative test between the two telegraphs, which was reduced to a test of Betancourt's system when Chappe refused to participate. Even though the telegraph was never put into service in France because of Chappe's opposition (Chappe was Director of the telegraph service [25], and later recognized that he used the fact that Betancourt and Breguet were foreign in order to defend the fact that the Government of the Republic could not favour foreigners over French nationals), the telegraph was highly praised by the academics. Finally, Betancourt's efforts were partially rewarded in Spain, where the line between Madrid and Aranjuez was established [26, 27] (It seems that only this part of the planned line was completed, in contrast to other authors who talk of the line Madrid-Cádiz [28]).

\section{Virtual Reconstruction}

For the virtual reconstruction of the telegraph, various sources have been consulted. Firstly, a search was carried out for existing preserved elements of the machinery or mechanism.

However, no existing machinery remains.

The next step was to compile graphical documentation, models and written material. In this case, are large amount of material was available, enough to obtain a close idea of the original design. The dossier mentioned above was consulted, as well as two models (figure 11) which belong to the collection of the Conservatoire des Arts in Paris.

A model of the telegraph was constructed for the travelling exhibition organized by the CEHOPU. The instrument functions correctly, but in contrast to the Parisian model, it is not made to scale (it does not have the same proportions as the actual telegraph), and therefore could not be used for this study. 
The dossier contains the two memoirs written by Betancourt. The first includes a plan (along with another plan which provides the report by Prony), while the second contains three plans. This information has been sufficient to be able to complete the modeling of the telegraph using advanced CAD techniques, despite contradictions in the materials used (the measurements of some of the elements differ between plans and the scale of the third plan is confusing).

In the process of generating the necessary geometry, a first version used AutoCAD (version with aligned telescopes), while a second version used SolidWorks (version with non-aligned telescopes), a software package which, unlike AutoCAD, allows for the parametric modification of each of the elements, as well as the creation of technical simulations which can be analysed from a mechanical point of view (figure 12).

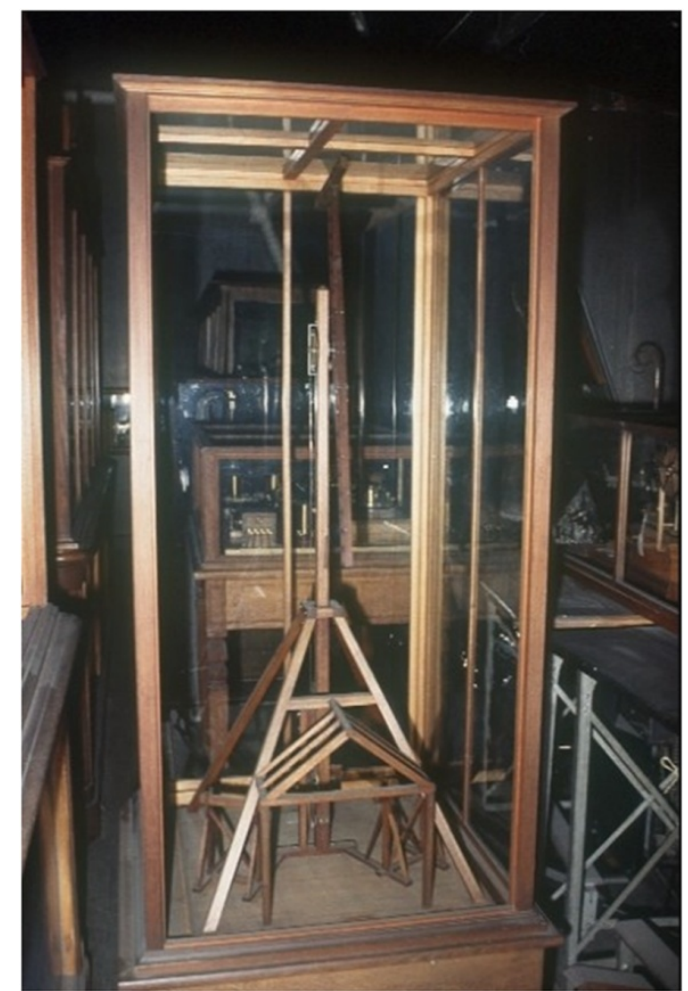

Figure 11. Model of the telegraph with oblique telescopes. Musée des arts et métiers (Paris).

The most realistic simulations and the computer animations were made with a specific program (Autodesk 3DS Max). In order to carry out this progress without having to regenerate the geometry of the components, the previously developed files were converted so that they were compatible with this software. This conversion was carried out respecting the implied restrictions in the precision of the geometry, and with the aim that the files were of a reasonable size.

The allocation of material has been carried out using commercial material libraries. These materials were determined from visible data in the coloured plan which accompanied the documents, and similar materials from the time were taken from various fields (naval construction, optical machinery, carpentry, etc.), and the materials of the models were also considered. For each of the objects in the virtual scene, the material allocated has been chosen to give the most realistic appearance possible from any angle. 
Another of the challenges faced was the generation of dynamic scenes. The movement of the telescopes on gimbal joints is a simple simulation in SolidWorks, but a complicated animation in 3DS Max; however, the increased realism that is obtained is a reward for this increased complication.

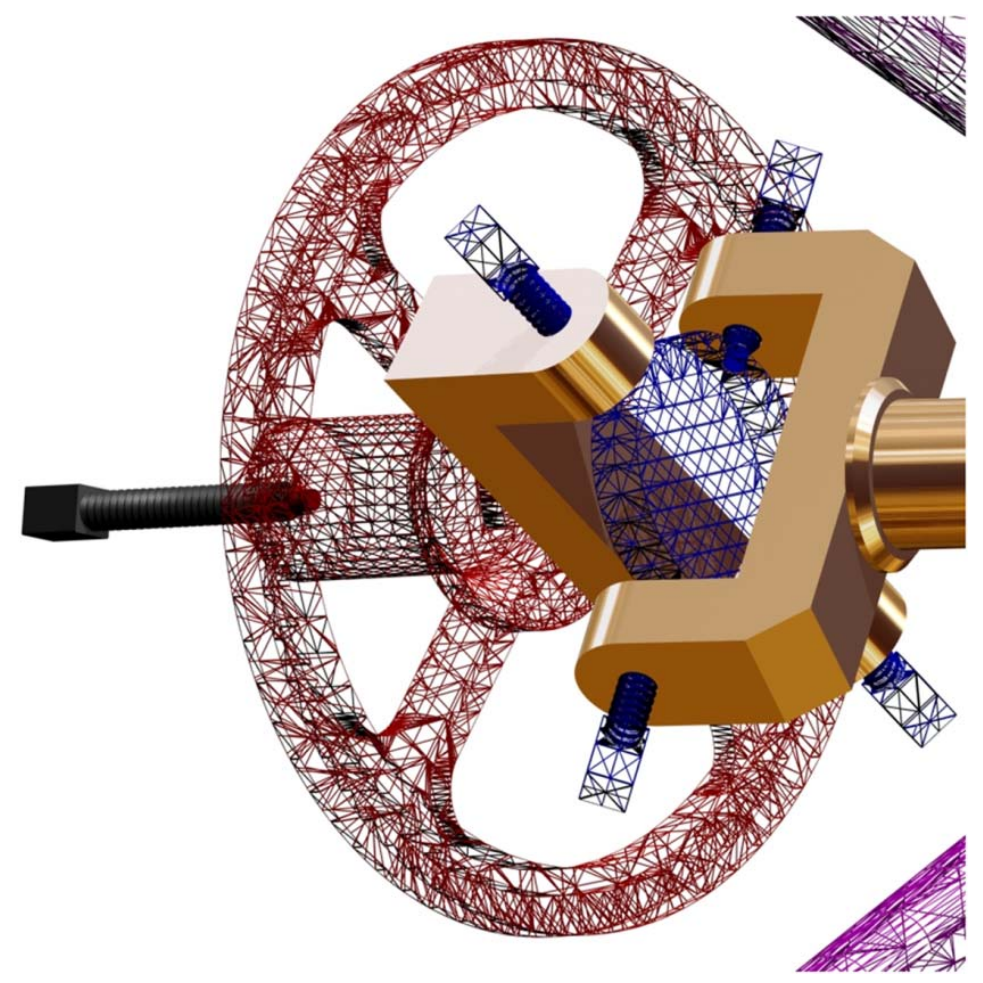

Figure 12. Geometric Modelling. Detail of the model generated with advanced CAD techniques.

\section{Conclusions}

The technical characteristics of the telegraph have been analyzed, with an analytical, numerical and graphical demonstration of the most controversial questions raised in its time because of individual interest which attempted to discredit it. Also, mistaken historical statements have been corrected, such as that which suggested that the knowledge of the laws of movement of certain elements (the gimbal joint) were discovered at a later time.

A rigorous reconstruction of the all the elements of the telegraph has been made, including the detail of some parts which have allowed us to demonstrate the majority of the assertions which Betancourt himself wrote to defend his project against the claims of those who were accusing him of plagiarism. Modern CAD (and CAX) systems are a powerful tool in scientific research, as they allow us to demonstrate the truth of statements made in the past without a large investment in equipment, while simulation tools allow us to make this information available to the scientific community and to the public in general.

Lastly, we have created a model of immersion which makes it possible for people with cultural and scientific curiosity to access the precise working of each of the parts of the telegraph, including the detailed movement during the realistic simulation of transmission from one station to the next. 


\section{References}

[1] J.I. Cuadrado Iglesias, M. Ceccarelli, El nacimiento de la Teoría de Máquinas y Betancourt, en el siglo de las luces: De la industria al ámbito agroforestal, Real Academia de Ingeniería, Zaragoza, 2005.

[2] C.S. Lopez-Cajun, J.I. Cuadrado Iglesias, M. Ceccarelli, Early Modern Activity on TMM by Lanz and Betancourt before 1830, $11^{\text {th }}$ IFToMM World Congress in Mechanism and Machine Science, 2004, Tianjin, 2004.

[3] O.Erogova, Ceccarelli M., J.I. Cuadrado Iglesias, C.S.Lopez-Cajún, V.E.Pavlov, Agustin Betancourt: an Early Modern Scientist and Engineer in TMM. Proceedings of ASME IDETC/CIE 2006 Mechanisms\&Robotics Conference, Philadelphia, 2006.

[4] M. Ceccarelli (editor), Distinguished Figures in Mechanism and Machine Science: Their Contributions and Legacies, Springer, Dordrecht, 2007.

[5] O. Egorova, Agustin Betancourt and his contribution to higher engineering education in Russia, 12th IFToMM World Congress, Besancon (France), 2007.

[6] V.E. Pavlov. Agustin Betancourt in Russia. Quaderns d'història de l'enginyeria. Vol. X. ETSEIB-UPC, Barcelona, 2009.

[7] S. Olivé Roig, Historia de la telegrafía óptica en España, Ministerio de Transporte, Turismo y Comunicaciones, Madrid, 1990.

[8] A. A. Huurdeman, The worldwide history of telecommunications, Wiley-IEEE, 2003.

[9] O. Pérez Sanjuán (coordinadora), De las señales de humo a la sociedad del conocimiento: 150 años de telecomunicaciones en España, COIT, Barcelona, 2006.

[10] I. Chappe, Histoire de la télégraphie, Imprimerie de Crapelet, Paris, 1824.

[11] C.M. D’Eymar, Au Directoire Exécutif, Manuscript, 1796.

[12] C.M. D’Eymar, Gazette Nationale ou Le Moniteur Universel (1797-11-6), Paris, 1797.

[13] http://betancourt.fundacionorotava.es

[14] G. Holzmann, B. Pehrson, The Early History of Data Networks, Wiley-IEEE Computer Society, 1994.

[15] http://www.tekniskamuseet.se

[16] A. Betancourt, A. Breguet, Description du Télégraphe inventé par les C. ${ }^{\text {ens }}$ Breguet et Betancourt, Manuscript, 1796.

[17] G. Prony, Rapport du citoyen Prony, Manuscript, Paris, 1796.

[18] C. Chappe, Mémoire sur le projet d'un nouveau télégraphe présenté au Directoire, Manuscript, Paris, 1796.

[19] C. Chappe, Gazette Nationale ou Le Moniteur Universel (1797-11-10), Paris, 1797.

[20] A. Betancourt, A. Breguet, Réponse aux observations faites par le citoyen Chappe sur le télégraphe proposé au Directoire par les citoyens Breguet et Betancourt, Paris, 1797.

[21] A. Betancourt, A. Breguet, Mémoire sur un nouveau Télégraphe et quelques ideés sur la langue télégraphique, Manuscript, Paris, 1797.

[22] Lagrange, Laplace, Borda, Prony, Coulomb, Charles y Delambre. Rapport sur un nouveau télégraphe, de l'invention des citoyens Bréguet et Bétancourt (Published in Mémoires de l'Institut National des Sciencies et Arts), Paris, 1797.

[23] J. M. de Lanz, A. de Betancourt, Ensayo sobre la composición de las máquinas, (facsímil de 1808), Castalia, Madrid, 1990.

[24] A. Mills, Robert Hooke's universal joint' and its application to sundials and the sundialclock, published on-line en Notes\&Records of the Royal Society, 2007.

[25] C. Chappe, Gazette Nationale ou Le Moniteur Universel (1798-04-29), Paris, 1798.

[26] I. Gonzalez Tascón, et al. Betancourt. Los inicios de la ingeniería moderna en Europa, Ministerio de Obras Públicas y Medio Ambiente, Madrid, 1996.

[27] J. Fernández Pérez, I. González Tascón, Ciencia, Técnica y Estado en la España ilustrada, Sociedad Española de Historia de las Ciencias y de las Técnicas, Zaragoza, 1990.

[28] A. Rumeu de Armas, Ciencia y tecnología en la España ilustrada, Turner, Madrid, 1980. 